\title{
Lightning $\mathrm{NO}_{\mathrm{x}}$ emissions over the USA constrained by TES ozone observations and the GEOS-Chem model
}

\author{
L. Jourdain ${ }^{1,}$, , S. S. Kulawik ${ }^{1}$, H. M. Worden ${ }^{2}$, K. E. Pickering ${ }^{3}$, J. Worden ${ }^{1}$, and A. M. Thompson ${ }^{4}$ \\ ${ }^{1}$ Jet Propulsion Laboratory, California Institute of Technology, 4800 Oak Grove Drive, Pasadena, CA 91109, USA \\ ${ }^{2}$ National Center for Atmospheric Research, P.O. Box 3000 Boulder, CO 80307, USA \\ ${ }^{3}$ NASA Goddard Space Flight Center, Greenbelt, MD 20771 USA \\ ${ }^{4}$ Department of Meteorology, Pennsylvania State University, University Park, PA 16802,USA \\ *now at: Laboratoire de Physique et Chimie de l'Environnement et de l'Espace et Université d'Orléans, Orléans, France
}

Received: 11 September 2008 - Published in Atmos. Chem. Phys. Discuss.: 14 January 2009

Revised: 21 October 2009 - Accepted: 25 November 2009 - Published: 8 January 2010

\begin{abstract}
Improved estimates of $\mathrm{NO}_{\mathrm{x}}$ from lightning sources are required to understand tropospheric $\mathrm{NO}_{\mathrm{x}}$ and ozone distributions, the oxidising capacity of the troposphere and corresponding feedbacks between chemistry and climate change. In this paper, we report new satellite ozone observations from the Tropospheric Emission Spectrometer (TES) instrument that can be used to test and constrain the parameterization of the lightning source of $\mathrm{NO}_{\mathrm{x}}$ in global models. Using the National Lightning Detection (NLDN) and the Long Range Lightning Detection Network (LRLDN) data as well as the HYPSLIT transport and dispersion model, we show that TES provides direct observations of ozone enhanced layers downwind of convective events over the USA in July 2006. We find that the GEOS-Chem global chemistry-transport model with a parameterization based on cloud top height, scaled regionally and monthly to OTD/LIS (Optical Transient Detector/Lightning Imaging Sensor) climatology, captures the ozone enhancements seen by TES. We show that the model's ability to reproduce the location of the enhancements is due to the fact that this model reproduces the pattern of the convective events occurrence on a daily basis during the summer of 2006 over the USA, even though it does not well represent the relative distribution of lightning intensities. However, this model with a value of $6 \mathrm{Tg} \mathrm{N} / \mathrm{yr}$ for the lightning source (i.e.: with a mean production of 260 moles NO/Flash over the USA in summer) underestimates the intensities of the ozone enhancements seen by TES. By imposing a production of 520 moles NO/Flash for lightning occurring in midlatitudes, which better agrees with the values proposed by the most recent studies, we de-
\end{abstract}

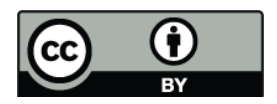

Correspondence to: L. Jourdain (line.jourdain@cnrs-orleans.fr) crease the bias between TES and GEOS-Chem ozone over the USA in July 2006 by $40 \%$. However, our conclusion on the strength of the lightning source of $\mathrm{NO}_{\mathrm{x}}$ is limited by the fact that the contribution from the stratosphere is underestimated in the GEOS-Chem simulations.

\section{Introduction}

Research on the strength and distribution of the source of nitrogen oxides $\left(\mathrm{NO}_{\mathrm{x}}=\mathrm{NO}+\mathrm{NO}_{2}\right)$ from lightning has been the subject of increasing literature in the past decade (for a review, see Schumann and Huntrieser, 2007). Indeed, a better knowledge of this source is required to understand $\mathrm{NO}_{\mathrm{x}}$ and ozone distributions in the troposphere, in particular in the upper troposphere where most of the lightning $\mathrm{NO}_{\mathrm{x}}$ emissions are deposited by thunderstorms (Pickering et al., 1998). The knowledge of this source is also needed to assess the present and future impact of anthropogenic sources on upper tropospheric ozone. $\mathrm{NO}_{\mathrm{x}}$ has an indirect climate impact via its effect on ozone and hydroxyl radical $(\mathrm{OH})$ concentrations. Hence, quantifying this source is also critical to understanding feedbacks between climate change and atmospheric chemistry (IPCC, 2007).

Over the United States, lightning contributes substantially to the ozone maximum observed in the upper troposphere over the southeastern United States in summer ( $\mathrm{Li}$ et al., 2005; Cooper et al., 2006, 2007). Analyses of observation campaigns have also demonstrated lightning contributions to the ozone and $\mathrm{NO}_{\mathrm{x}}$ concentrations over the middle US (e.g.: Ridley et al., 1994; Jaegle et al., 1998; Stith et al., 1999; DeCaria et al., 2000, 2005), the East Coast of the US (Hudman et al., 2007) and over the downwind Atlantic

Published by Copernicus Publications on behalf of the European Geosciences Union. 


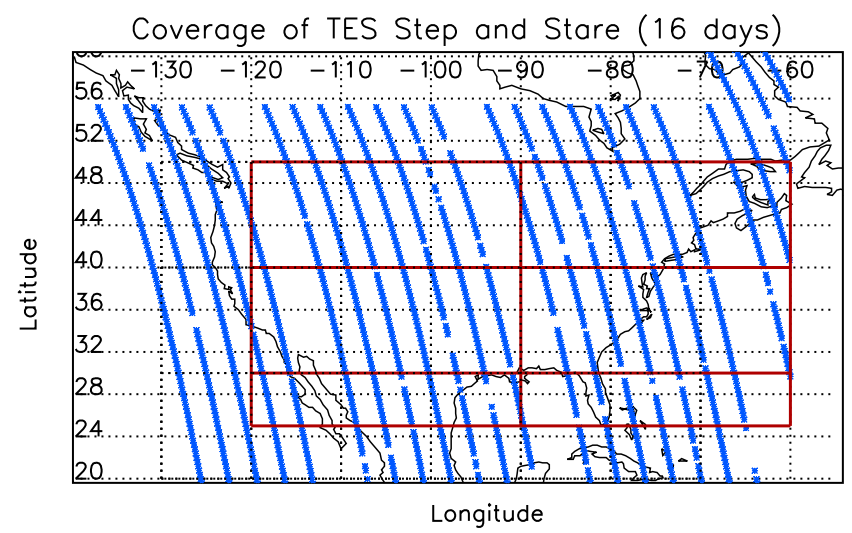

Fig. 1. Coverage of the TES Step and Stare for a 16 days period in July 2006 (blue). The different regions that are distinguished for the statistics in Fig. 7 are presented in red.

region (e.g.: Brunner et al., 1998, 2001; Liu et al., 1999; Thompson et al., 1999; Jeker et al., 2000; Crawford et al., 2000; Allen et al., 2000) in summer and fall. The relative contribution of the lightning source to the ozone observed over these regions vs the contributions of the transport from the boundary layer by convection and from the stratosphere is a source of debate. Li et al. (2005) show that the elevated ozone concentrations in the upper troposphere over the southeastern region in summer are mainly due to convective transport of pollution created in the boundary layer which are lifted and trapped in an anticyclone, while ozone production in-situ, from ozone precursors and $\mathrm{NO}_{\mathrm{x}}$ from lightning, also contributes to this enhancement but plays a secondary role. Thompson et al. (2007a, b), using ozone and P-T-U soundings, found persistent stratospheric influences over northeastern North America free tropospheric ozone in summer 2004 (IONS-04; Intercontinental Transport Experiment (INTEX) Ozonesonde Network Study) and south central North America in summer 2006 (Thompson et al., 2008). In both cases, stratospheric origins were implicated in 20$25 \%$ of the tropospheric ozone column, with convection and lightning sources somewhat less, 10-15\%. Detailed analysis of the IONS site at Beltsville, Maryland (39 N, 77 W) over four summers, 2004-2007, found that stratospheric influences on tropospheric ozone above the boundary layer, were typically $>30 \%$ of the column (Yorks et al., 2009). Cooper et al. $(2006,2007)$ used a FLEXPART approach to IONS sonde analysis. When stratospheric ozone influences are filtered from the IONS sondes, upper tropospheric ozone origins are dominated by lightning $\mathrm{NO}_{\mathrm{x}}$, more than $80 \%$ between 9-11 km.

Here, we report new satellite ozone observations that can be used to test and constrain the parameterization of the lightning source of $\mathrm{NO}_{\mathrm{x}}$ in global models. In the present study, the vertical ozone profiles from TES are used in conjunction with NLDN and LRLDN lightning data, ozonesonde measurements from the IONS project, and the GEOS-Chem model to investigate our understanding of lightning emissions over the United States during summer 2006.

\section{Data, model and simulations}

\subsection{TES observations}

The TES instrument is an infrared Fourier transform spectrometer with a spectral resolution of $0.1 \mathrm{~cm}^{-1}$ and a spectral range from $650-2250 \mathrm{~cm}^{-1}$ (Beer et al., 2001) which was launched aboard the NASA's Aura satellite in July 2004. Standard products include vertical profiles of ozone, $\mathrm{CO}$ and water vapor obtained from nadir observations. The vertical resolution of TES nadir ozone retrievals is about $6 \mathrm{~km}$ for cloud-free scenes, with sensitivity to both the lower and upper troposphere (Worden et al., 2004; Bowman et al., 2006; Jourdain et al., 2007). The quality of TES ozone retrievals in the troposphere has been evaluated using ozonesonde measurements (Worden et al., 2007; Nassar et al., 2008) as well as lidar measurements (Richards et al., 2008). TES total and stratospheric ozone columns have also been computed and compared with the observations from the Ozone Monitoring Instrument and Microwave Limb Sounder (Osterman et al., 2008). The algorithm used for retrieving the vertical trace gas profiles from TES radiances is based on an optimal estimation method (Rodgers, 2000) and is described in Worden et al. (2004) and Bowman et al. (2006). The relationship between elements of the true trace gas profile and of the retrieved profile can be expressed as:

$\hat{\boldsymbol{x}}=\mathbf{x}_{a}+\mathbf{A}\left(\mathbf{x}-\mathbf{x}_{a}\right)+\mathbf{G} \varepsilon$

where $\hat{\boldsymbol{x}}$ is the logarithm of the retrieved profile, $\mathbf{x}_{a}$ is the logarithm of the a priori constraint obtained from monthly mean profiles simulated with the MOZART-3 model (Horowitz et al., 2003) and binned in $10^{\circ}$ latitude $\times 60^{\circ}$ longitude grids, $\mathbf{x}$ is the logarithm of the true profile, $\varepsilon$ is the radiance measurement noise, and $\mathbf{G}$ is the gain matrix converting the noise to spectral measurement error. The averaging kernel (A) describes the sensitivity of the retrieved profile to the perturbations of the true state.

TES has several modes of observations (Beer et al., 2006). In this study, we use the Step and Stare mode that has nadir target spaced about $0.4^{\circ}$ apart and typically covers a $50^{\circ}$ latitude range. In order to study the ozone budget over the United States during the summertime and the pollution export from North America, 144 Step and Stare were performed over the North American and North Atlantic regions between 4 July and 21 August 2006. Figure 1 shows an example of the Step and Stare track performed during that period for 16 days coverage. For this study, we use the 39 Step and Stare performed over North America during July 2006. 


\subsection{Lightning data}

Lightning data are used for two purposes in this study. First, we used them to relate ozone enhanced layers in the TES data to lightning events. Secondly, we also impose the distribution of lightning in the model according to these observations for our baseline and sensitivity simulations (see details in Sect. 2.3).

The National Lightning Detection Network (NLDN) detects cloud-to-ground (CG) flashes over the continental USA with a detection efficiency of at least 90\% (Grogan, 2004). For regions outside the continental USA, CG flashes were detected with the Long Range Lightning Detection Network (LRLDN). The detection efficiency is $60-80 \%$ at $60 \mathrm{~N}$ and $40-60 \%$ at $21 \mathrm{~N}$ as reported in Cooper et al. (2006). We took a detection efficiency of $50 \%$ for all the LRLDN data and used these data only above $25 \mathrm{~N}$. Note also that LRLDN does not include data over Canada in July 2006.

We also used the LIS/OTD 2.5 Degree Low Resolution Annual Climatology Time Series (Christian et al., 2003) to regionally adjust lightning flash rates in the model on a monthly basis (see details in Sect. 2.3).

\subsection{GEOS-Chem simulations}

We use the GEOS-Chem v7.04.09 global 3-D tropospheric chemistry and transport model with a horizontal resolution of $2^{\circ} \times 2.5^{\circ}$ and 55 layers in the vertical (http://acmg.seas. harvard.edu/geos/geos_welcome.html). This model has been described by Park et al. (2004) and a simulation driven by the assimilated meteorological GEOS-4 data from the NASA Global Modeling and Assimilation Office (GMAO) has been recently globally evaluated by $\mathrm{Wu}$ et al. (2006). Below we describe the different simulations performed for this study:

\subsection{1 $S_{\text {base }}$}

For this simulation, the lightning emission parameterization is based on Price and Rind (1992) and described in Wang et al. (1998). The lightning source is scaled globally to $6 \mathrm{Tg}$ $\mathrm{N} / \mathrm{yr}$. Previous work showed that $\mathrm{NO}_{\mathrm{x}}$ concentrations predicted by the GEOS-Chem model were underestimated in the upper troposphere over the midlatitudes in summer (Martin et al., 2006; Hudman et al., 2007). Martin et al. (2006) attribute this problem to the incorrect spatial distribution of lightning activity in the model. Indeed, because lightning $\mathrm{NO}_{\mathrm{x}}$ emissions are only scaled globally, any shortcoming in the lightning distribution in the model is reflected in the $\mathrm{NO}_{\mathrm{x}}$ emissions distribution. Sauvage et al. (2007) also show the importance of lightning repartition on the ozone field predicted by the GEOS-Chem model. In the present study, we have regionally scaled the lightning in the model to match the OTD/LIS climatology (Christian et al., 2003) on a monthly basis. To do this, we have run the lightning scheme of the GEOS-Chem model "off line" for the period August 2005-
August 2006. The lightning flashes are then scaled regionally to match OTD/LIS on a monthly basis. The resulting flashes are also scaled to obtain an annual mean of $44 \mathrm{~F} / \mathrm{s}$ globally, again consistent with OTDL/LIS climatology (Christian et al., 2003). We then simulate again the same period and $\mathrm{NO}_{\mathrm{x}}$ emissions are scaled to $6 \mathrm{Tg} \mathrm{N} / \mathrm{yr}$. Over North America midlatitudes $(25-50 \mathrm{~N})$, the resulting $\mathrm{LNO}_{\mathrm{x}}$ emissions total $0.1 \mathrm{Tg} \mathrm{N}$ for July 2006. It is two times higher than without this scaling. This is due to the fact that the original GEOSChem model tends to overestimate lightning in the tropical regions and hence place too much of the $6 \mathrm{Tg} \mathrm{N} / \mathrm{yr}$ in these regions, as noted in Martin et al. (2006). This is also shown in Fig. 2, where the initial and modified distributions of lightning for July 2006 in GEOS-Chem are presented. Note that the mean NO production per flash over the United States during July 2006 is 260 moles of NO/Flash. The value used in our baseline simulation is very close to the most recent best estimate by Schumann and Huntrieser (2007) of 250 moles $\mathrm{NO} /$ Flash. Finally, we have performed a full simulation with the GEOS-Chem model for the period January 2006-August 2006 driven by the GEOS-4 data updated every 3-6h using the scaling factors for the lightning parameterization described before. Note that this is now the method adopted to distribute lightning in the most recent version of the GEOSChem model (Lee Murray, personal communication), but this was not available in the standard GEOS-Chem at the time of our study. Initial concentrations are from the Near-Real-time Simulation of the GEOS-Chem model.

\subsubsection{S Soanth}

In this simulation, anthropogenic sources over North America, for latitude ranging between $25 \mathrm{~N}-50 \mathrm{~N}$, have been turned off.

\subsubsection{S $S_{\text {noligh }}$}

To study the influence of the lightning $\mathrm{NO}_{\mathrm{x}}$ emissions from midlatitudes North America on the ozone field predicted by GEOS-Chem, we have also performed an additional simulation with the GEOS-Chem model, in which lightning $\mathrm{NO}_{\mathrm{x}}$ emissions over North America, for latitude ranging between $25 \mathrm{~N}-50 \mathrm{~N}$, have been turned off.

\subsection{4 $S_{\text {noligh+noanth }}$}

In this simulation, lightning and anthropogenic sources over North America, for latitude ranging between $25 \mathrm{~N}-50 \mathrm{~N}$, have been turned off.

\subsection{5 $\mathrm{S}_{\mathrm{NLDN}}$}

We performed another simulation in which the lightning over the United States and up to few hundred kilometers off the coasts and borders of the United States in the GEOS-Chem 

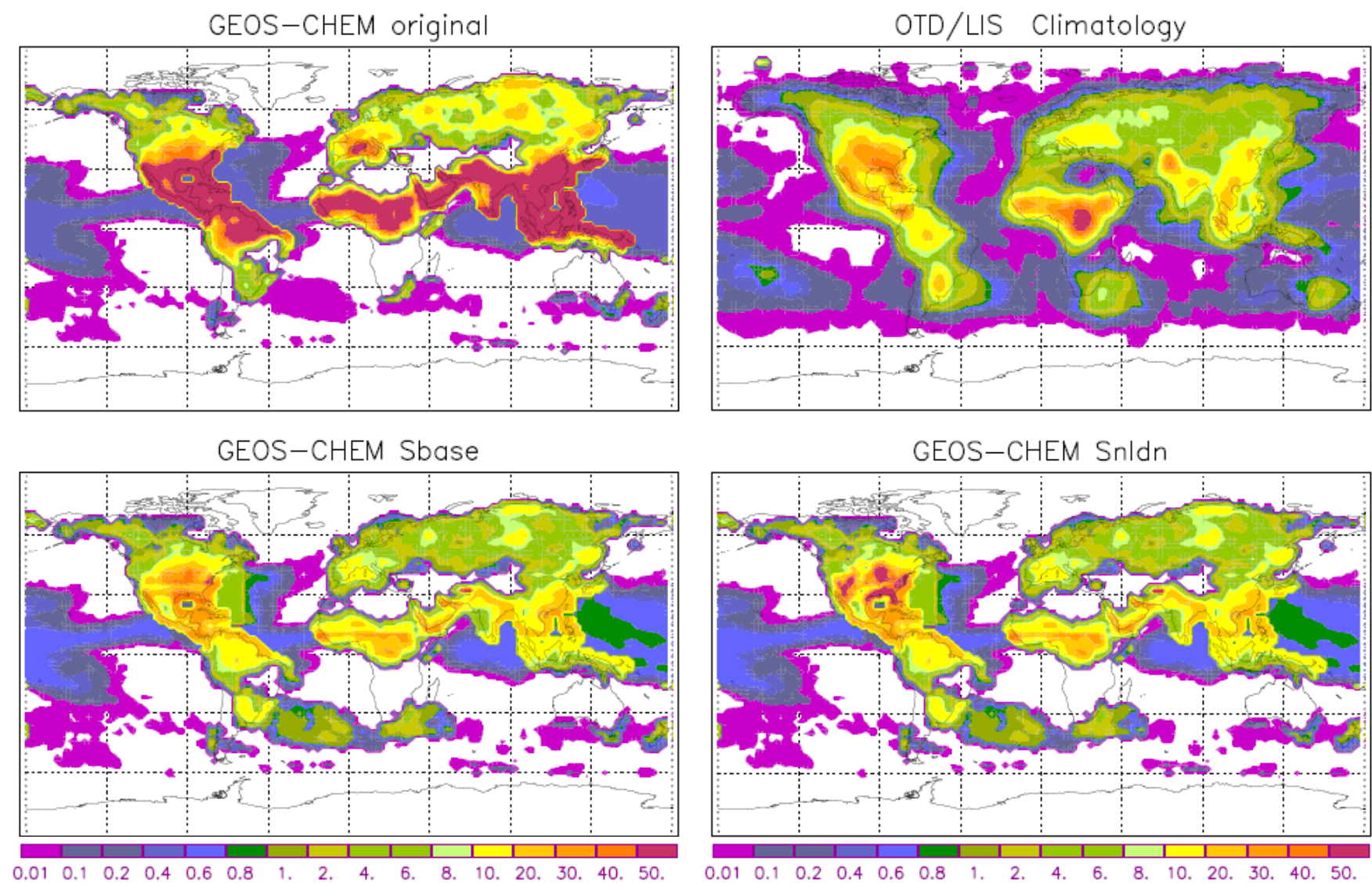

Fig. 2. Top: July Monthly mean Lightning flash densities simulated by GEOS-Chem for 2006 (left) and derived from 5 years of OTD and LIS observations (see text for more details). Bottom: July Monthly mean Lightning flash densities simulated by GEOS-Chem for 2006, when GEOS-Chem is scaled regionally to OTD/LIS on a monthly basis (simulation Sbase, left) and then scaled gridbox by gridbox to NLDN and LRLDN observations over the North America on a daily basis (simulation SNLDN, right).

model are scaled on a daily basis to NLDN and LRLDN observations. Note that, to account for the intracloud fashes (IC), we have applied to the NLDN and LRLDN data a IC:CG ratio of 3, which corresponds to the mean value of this ratio over the USA calculated by Boccippio et al. (2001). We have then gridded the lightning data on the GEOS-Chem grid and taken the daily average. This resulting lightning distribution is used to scale the lightning activity in the model on a daily basis. The resulting $\mathrm{LNO}_{\mathrm{x}}$ source totals $0.14 \mathrm{Tg} \mathrm{N}$ in July 2006 over North America midlatitudes (25-50 N). It is higher than in Sbase because more lightning are observed in July 2006 in NLDN and LRLDN data than in OTD/LIS climatology as shown in Fig. 2.

\subsection{6 $\mathrm{S}_{\mathrm{ligh} \times 2}$}

In this simulation, the $\mathrm{NO}_{\mathrm{x}}$ production by flash is increased by 2 in midlatitudes compared to $S_{\text {NLDN }}$. The production of $\mathrm{NO}_{\mathrm{x}}$ by flash is around 520 moles/Flash in mean. This value is close to the updated $\mathrm{NO}_{\mathrm{x}}$ production per flash of De Caria et al. (2005) of 460 moles/Flash based on the analy- sis of the STERAO (Stratosphere-Troposphere ExperimentRadiation, Aerosols and Ozone) campaign and the mean value of 500 moles/Flash reported by Ott et al. (2010) from cloud-resolved modeling analyses of midlatitude and subtropical storms constrained by observed flash rates and anvil aircraft observations. Cooper et al. (2006) found that using a production rate of 460 moles/flash in the FLEXPART model provided acceptable comparison with aircraft data from the International Consortium on Atmospheric Transport and Transformation (ICARTT).

Hudman et al. (2007) showed that with a value of $500 \mathrm{~mol} /$ Flash, the model $\mathrm{NO}_{\mathrm{x}}$ field agrees better with observations from the ICARTT aircraft campaign over the Southeast United States, but the model was still too low in the Midwest and Southeast due to a misrepresentation of the flash counts. Assuming larger $\mathrm{NO}_{\mathrm{x}}$ production per flash in midlatitudes is also consistent with the analysis of Huntrieser et al. (2008). Indeed, they suggest based on field experiments that the higher vertical wind shear in subtropical and midlatitudes thunderstorms lead to longer stroke lengths and thus higher $\mathrm{NO}_{\mathrm{x}}$ production per flash than in tropical 

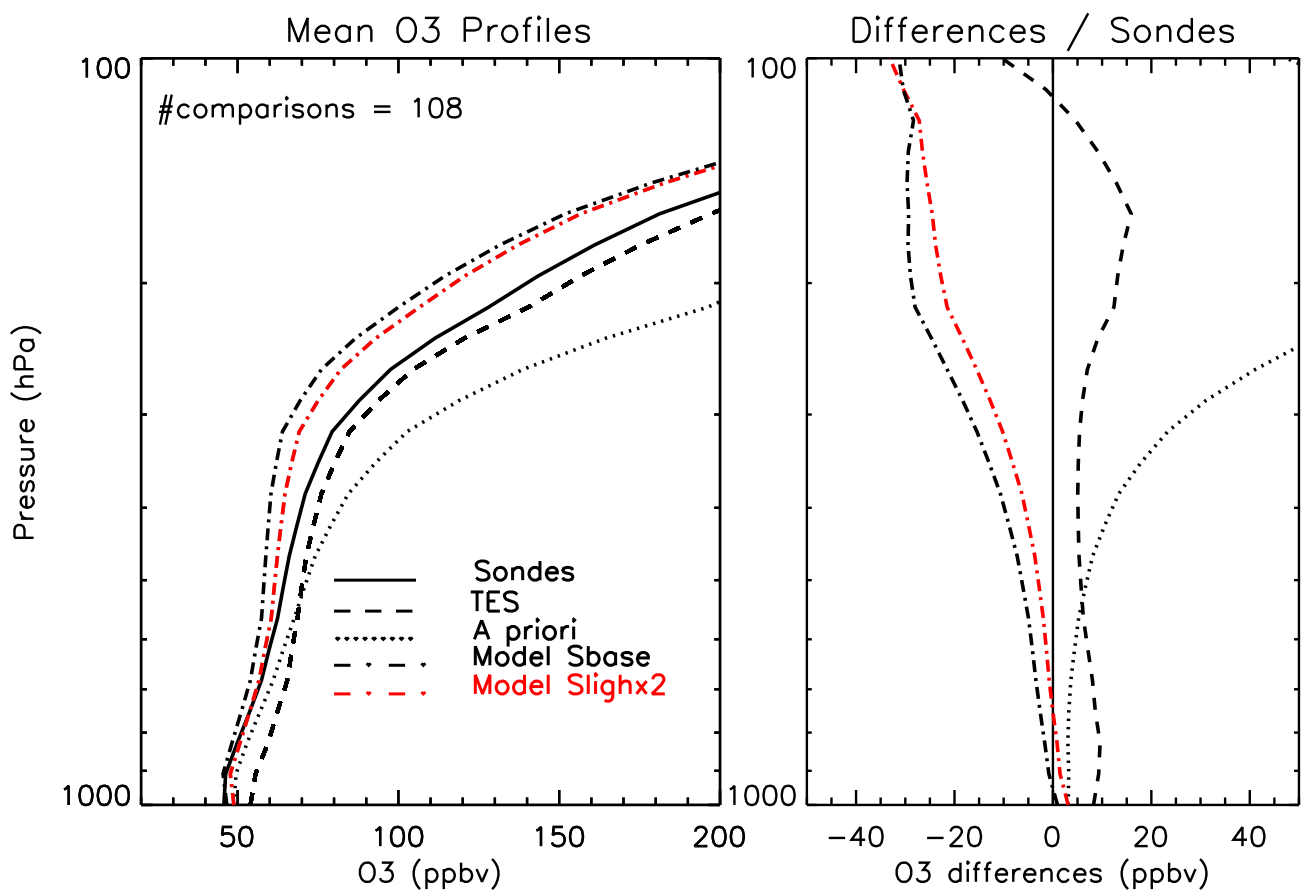

Fig. 3. Left: comparison between the mean ozonesondes profile from the IONS project (black), mean TES profile (black dashed line), mean TES apriori profile (black dotted line) and mean GEOS-chem profiles for the $\mathrm{S}_{\text {base }}$ simulation (black dashed-dotted line), $\mathrm{S}_{\text {lighx2 }}$ simulation (red dashed-dotted line). Right : Mean difference between ozonesondes measurements and respectively TES measurements (black dashed line), mean TES apriori profile (black dotted line), mean GEOS-chem profile for the $S_{\text {base }}$ simulation (black dashed-dotted line), $S_{\text {lighx2 }}$ simulation (red dashed-dotted line).

thunderstorms. Note also that with a NO production of around 520 moles/Flash in midlatitudes, the global $\mathrm{LNO}_{\mathrm{x}}$ production would be around $8 \mathrm{Tg} \mathrm{N} / \mathrm{yr}$ which is within the range suggested in the comprehensive review of lightning $\mathrm{NO}_{\mathrm{x}}$ by Schumann and Huntrieser (2007). The resulting source totals $0.28 \mathrm{Tg} \mathrm{N}$ over North America midlatitudes $(25-50 \mathrm{~N})$ for July 2006 . Note that this value is consistent with Hudman et al. (2007), who simulated a lightning source of $0.45 \mathrm{Tg} \mathrm{N}$ for 1 July to 15 August 2004 period when using 500 moles NO/Flash.

Note that the simulations $\mathrm{S}_{\text {noligh }}, \mathrm{S}_{\text {noligh+noanth }}, \mathrm{S}_{\text {noanth }}$, and $\mathrm{S}_{\text {lighx2 }}$ start the 1 March 2006. The simulation $\mathrm{S}_{\mathrm{NLDN}}$ starts the 1 July 2006. All the sensitivity simulations begin with initial concentrations taken from the simulation $S_{\text {base }}$.

\subsection{Evaluation of TES and GEOS-Chem ozone with IONS ozonesondes}

TES ozone profiles and GEOS-Chem profiles used in this study have been compared to the ozonesonde measurements from the Intercontinental chemical transport experiment Ozoneseonde Network Study (IONS) 2006 campaign (Thompson et al., 2007a, b, 2008) to provide validation specific to the North American summer conditions. The coincidence criteria for the comparison with sondes are $\pm 3 \mathrm{~h}$ and $\pm 200 \mathrm{~km}$, the number of comparisons is 108 . Note that for all the comparisons with TES, the GEOS-Chem and ozonesonde profiles are interpolated onto the TES pressure grid. Then, in order to account for the vertical sensitivity of each TES retrieval, they are transformed using the TES observation operator, which is composed of the averaging kernel and the a priori profile using Eq. (1) without the measurement error term $\mathbf{G} \varepsilon$ (Bowman et al., 2006; Worden et al., 2007).

Figure 3 shows the mean ozonesonde profiles, the mean TES profiles, along with the mean GEOS-chem profiles for the different simulations $\left(S_{\text {base }}, S_{\text {lighx2 }}\right)$ and the mean TES apriori profiles. TES data compare better to the ozonesondes than the TES a priori but the ozone in TES is overestimated by 5 to $15 \mathrm{ppbv}$ in the upper troposphere. The overestimation of TES in the upper troposphere is consistent with the previous work of validation of TES using ozonesondes measurements in Worden et al. (2007) and Nassar et al. (2008) as well as with lidar measurements by Richards et al. (2008). We will focus our study at $300 \mathrm{hPa}$ where the bias of TES compared to ozonesondes is about $+5 \mathrm{ppbv}$.

The GEOS-Chem baseline simulation $\left(\mathrm{S}_{\text {base }}\right)$ underestimates ozone mixing ratio by up to $30 \mathrm{ppbv}$ in the upper troposphere. At $300 \mathrm{hPa}$, the bias is $-17 \mathrm{ppbv}$. A similar underestimation of the GEOS-Chem model in the upper troposphere compared to IONS 2006 was also found by Parrington et al. (2008). In the simulation $\mathrm{S}_{\text {lighx2 }}$, where $\mathrm{NO}_{\mathrm{x}}$ production 

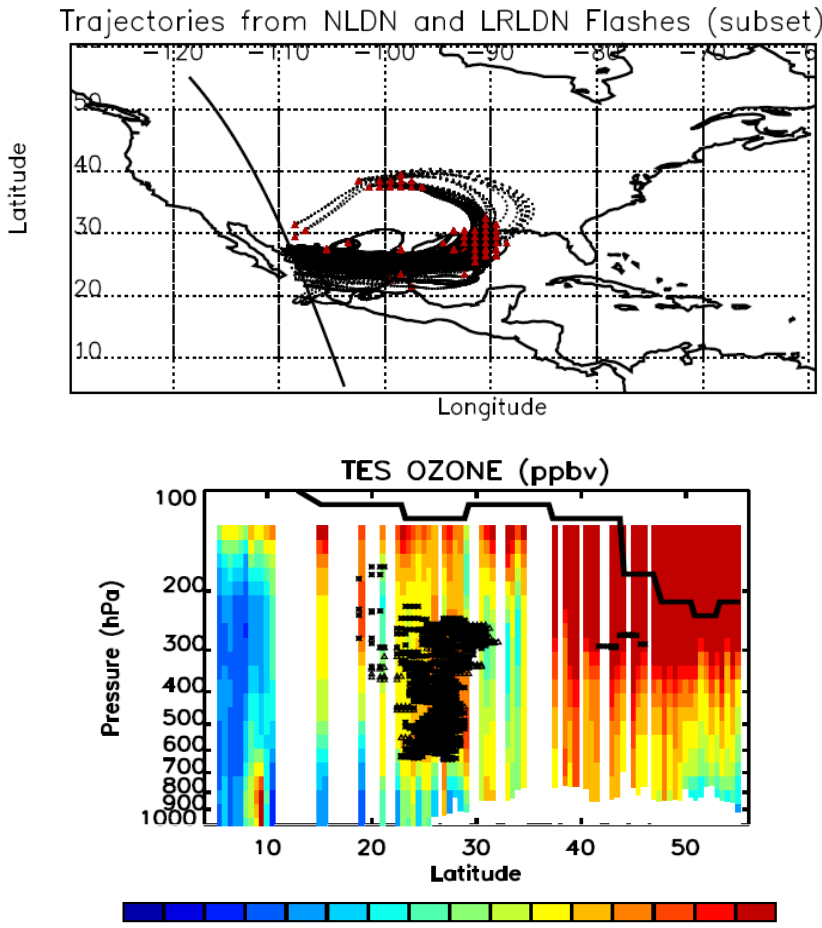

5. 10. 20. 25. 30. 35. 40. 45, 50. 55, 60. 70. 80. 90, 100.110 .

Fig. 4. Top: five-day forward trajectories initialized from the location and time of the $1 \times 1$ gridded and hourly averaged NLDN and LRLDN data (red triangles) and intersecting a TES track on 12 July 2006 within \pm 1 degree latitude, \pm 1 degree longitude and \pm 1 h. Bottom: cross section pressure-latitude of mean ozone volume mixing ratio retrieved by TES along the same TES track that shown above. The black symbols represent the trajectories that intersect this particular TES track within \pm 1 degree latitude, \pm 1 degree longitude and $\pm 1 \mathrm{~h}$.

per flash is increased by a factor of 2 and flash rates are based on NLDN and LRLDN, ozone in GEOS-Chem increases by about $10 \mathrm{ppbv}$ throughout the upper troposphere. This shows that ozone mixing ratios simulated by GEOS-Chem are very sensitive to the lightning $\mathrm{NO}_{\mathrm{x}}$ emissions parameterization. This suggests that an underestimation of this source could contribute to the discrepancy between GEOS-Chem and measurements (TES and IONS). However, the variation of the bias with altitude suggests also an underestimation of the downward ozone flux from the stratosphere by the model. Indeed, the difference between $S_{\text {base }}$ and $S_{\text {lighx } 2}$ at $120 \mathrm{hPa}$ is zero while the bias is about $25 \mathrm{ppbv}$. To conclude, the differences between GEOS-Chem and measurements (IONS and TES) suggest that contributions from the stratosphere and/or lightning could be larger than predicted by the GEOS-Chem model. The present study focuses on the treatment of the lightning source in the GEOS-Chem model using profiles from TES, which have better spatial coverage than sondes, as well as NLDN and LRLDN data and the Hysplit model.

\section{Results}

\subsection{Evidence of lightning $\mathrm{NO}_{\mathrm{x}}$ emissions influence in the TES data}

\subsubsection{Example of the 12 July 2007}

Figure 4 shows a case where ozone enhanced layers seen by TES on 12 July 2006 can be related to lightning events. In this figure, the forward trajectories are calculated with the HYSPLIT transport and dispersion model (Draxler and Rolph, 2003) and initialized from locations where the $1 \times 1$ gridded and hourly averaged NLDN and LRLDN indicates flashes. The trajectories shown are those that intersect the TES track within \pm 1 degree latitude, \pm 1 degree longitude and $\pm 1 \mathrm{~h}$. These trajectories show that the air parcels are trapped in an anticyclone, a typical feature of the upper atmospheric circulation during summer over the US (Li et al., 2005). The ozone retrievals along the TES track are shown in Fig. 4. The intersections between the TES track and the trajectories, indicated by black symbols in Fig. 4, are collocated with an ozone enhancement layer in the middle and upper troposphere. In this layer, TES observes ozone values up to $100 \mathrm{ppbv}$. We have calculated the degrees of freedom for signal (DOF), as defined in Rodgers (2000), to quantify TES vertical sensitivity to the atmospheric variability. The DOF for the whole tropospheric profile varies between 1.5 and 1.8 along the TES track as shown in Fig. 5. For the profiles showing the ozone enhanced layers between 25-30 degrees, the middle/upper tropospheric ( $500 \mathrm{hPa}$ to tropopause) part of the retrievals have a DOF larger than 1. This shows that TES is sensitive to the ozone variability in this region. This is further confirmed by the analysis of the a priori (not shown), which does not present this ozone enhanced layer. For comparisons with TES, the model profiles from the simulation $S_{\text {base }}$ are sampled along the Aura orbit track at the observation times and modified as explained in Sect. 2.4 for comparison with TES. We find that the GEOS-Chem model also shows the ozone enhanced layer seen by TES. The difference between the GEOS-Chem simulations with and without the lightning source is also shown along the TES track, confirming that lightning $\mathrm{NO}_{\mathrm{x}}$ emissions contribute to the ozone enhancement seen by TES. In particular, the model predicts an increase of the ozone up to $16 \mathrm{ppbv}$ due to the lightning emissions. However, the ozone values in the ozone enhanced layer in the model simulation are weaker than in TES by about 25 ppbv. As described in Bowman et al. (2006), differences between TES and GEOS-Chem should be compared to TES reported observational errors (sum of the measurement and cross-state errors estimates). This error is typically about 5-10 ppbv for the retrievals between 25-30 in latitude in the middle/upper troposphere. This suggests that the difference between TES and GEOS-Chem is significant. The reasons for discrepancies are investigated in Sect. 3.2. 

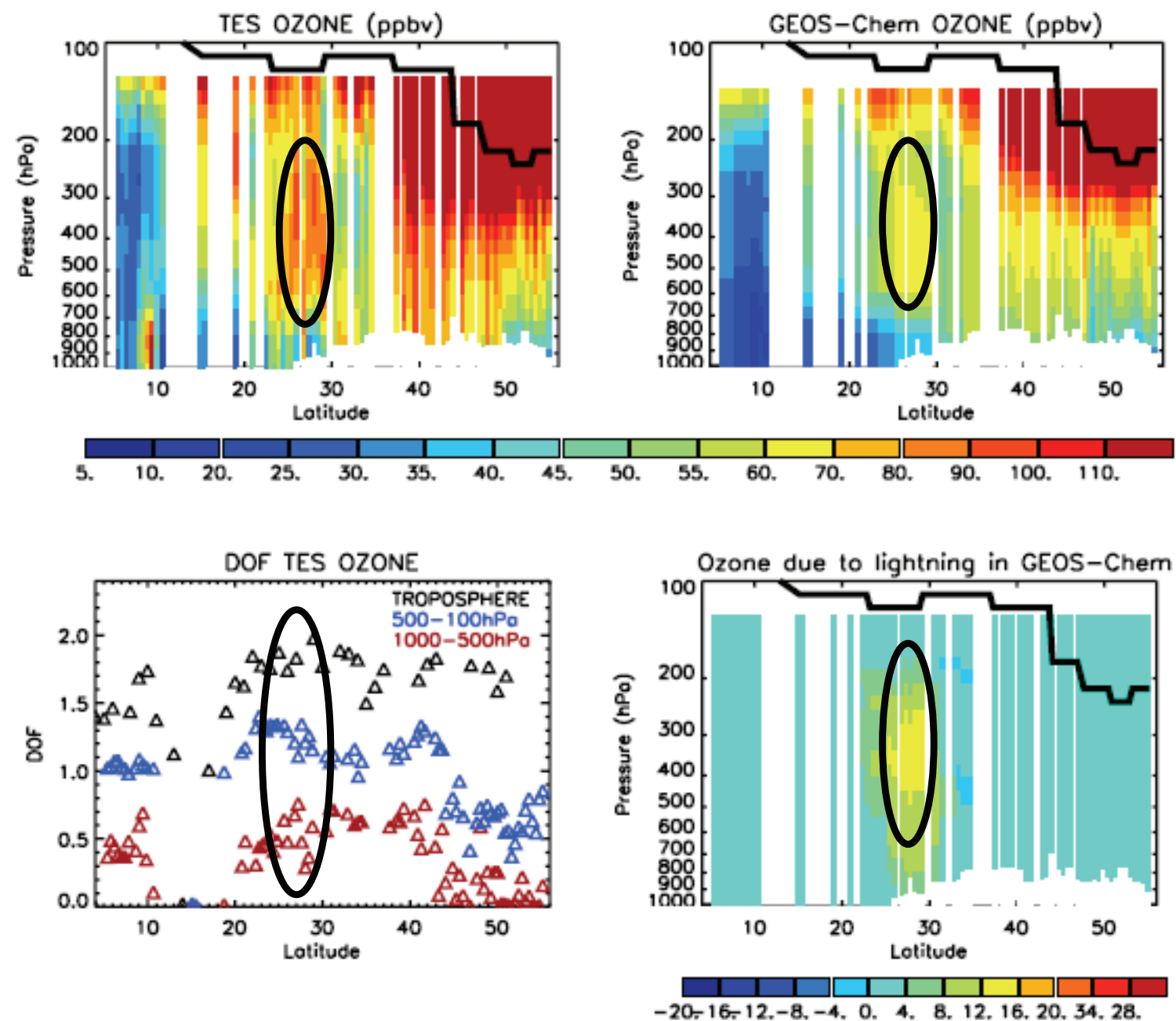

Fig. 5. Top: cross section pressure-latitude of mean ozone volume mixing ratios retrieved by TES (left) and simulated by GEOS-Chem (right) along the particular TES track shown in Fig. 4. Bottom: latitudinal variation of the DOF for TES ozone retrievals for the whole troposphere (black triangle), the surface-500 hPa region (red triangles), the $500 \mathrm{hPa}-100 \mathrm{hPa}$ region (blue triangles) for the same TES track (left) and cross section pressure-latitude of the difference in ozone between the simulation Sbase and Snolight (right). The black circle represents the area downwind of the recent lightning events as shown in Fig. 4.

\subsubsection{Generalization to North America}

We now show results for TES and GEOS-Chem over all of North America. Figure 6 shows a map of the ozone mixing ratios retrieved by TES over the USA averaged over the 250 and $350 \mathrm{hPa}$ vertical domain. Only the measurements taken between the 4 and 18 July 2006 are shown here on the map to avoid the overlapping of symbols. In this map, we have distinguished measurements recently influenced by lightning (large filled dots) and non-recently influenced (small filled dots) according to our analysis using HYSPLIT and flashes from NLDN and LRLDN. For this analysis, "recently influenced by lightning" means that the air masses sampled by TES should have passed through a region of lightning activity less than 5 days before the TES measurements. In Fig. 6, we show as well the corresponding GEOS-Chem
$\left(S_{\text {base }}\right)$ ozone mixing ratios sampled along the TES track and modified as explained in Sect. 2.4 for comparison with TES. We also show the difference between TES and GEOS-Chem and the ozone changes due to the lightning source in the model.

As for the particular case presented previously, these figures show ozone enhancements in TES at intersections with forward trajectories emanating from NLDN and LRLDN flashes, i.e.: downwind of convective events. These ozone enhancements are clearly seen over the Pacific Ocean between $25-30 \mathrm{~N}$, West of Mexico and North West of the Gulf of Mexico, where color gradients between recently influenced by lightning measurements (large filled dots) and non recently influenced by lightning measurements (small filled dots) are observed. In the southeastern United States, the influence of recent convection (as shown by the presence 

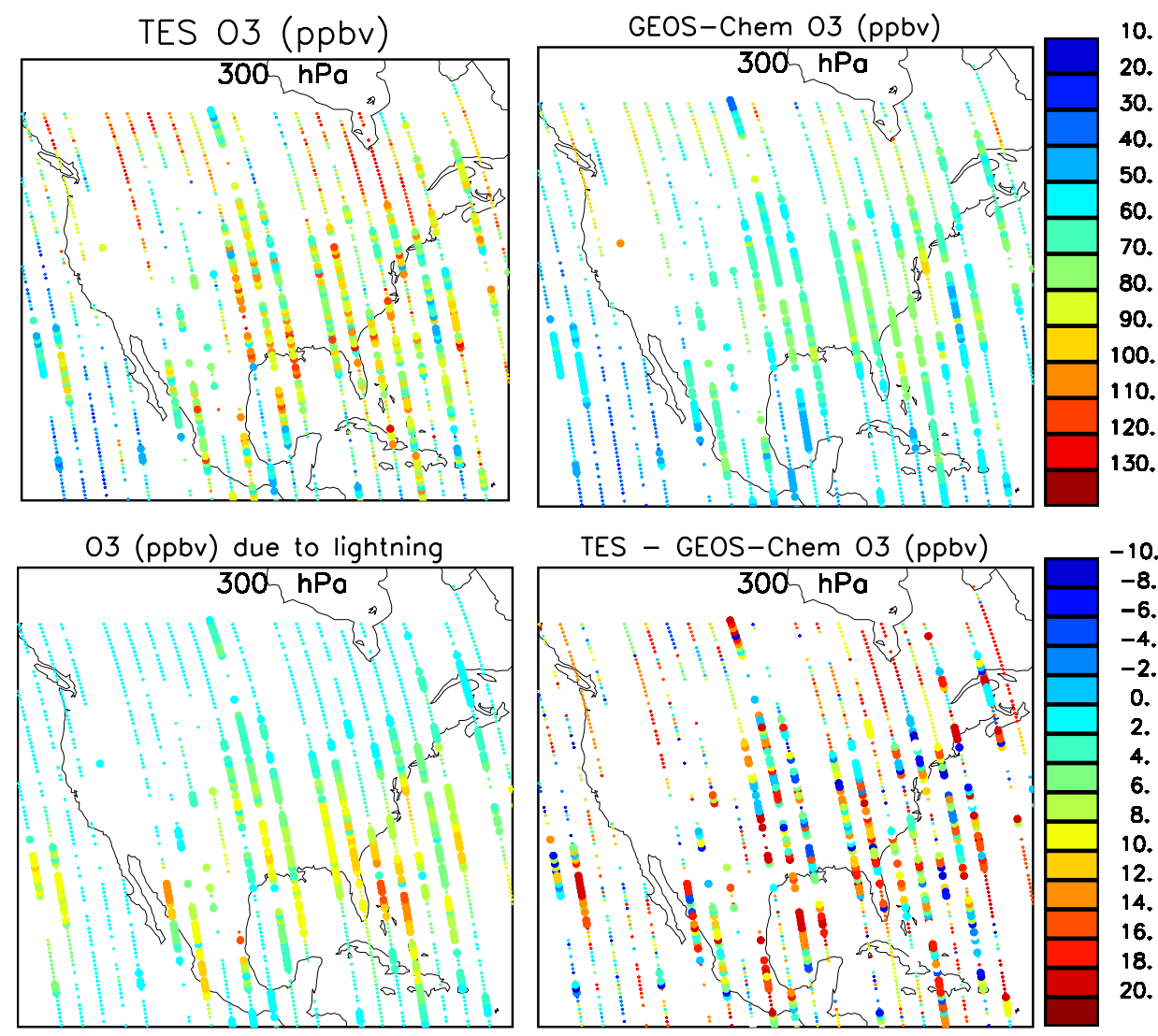

Fig. 6. Top: ozone mixing ratios over the North America averaged over the 250 and $350 \mathrm{hPa}$ vertical domain retrieved by TES (left) and simulated by GEOS-Chem (right). Bottom: difference in ozone between the simulation Sbase and Snoligh (left), difference between TES and GEOS-Chem Sbase mean ozone mixing ratios (right). Large filled circles represent the recently influenced by lightning as found by the analysis using HYSPLIT and NLDN and LRLDN. Note that only the measurements taken between the 4 and 18 July 2006 are shown here on the map to avoid the overlapping of the symbols.

of large filled dots) is observed everywhere. The Fig. 6 also shows that ozone mixing ratios in the upper troposphere in the GEOS-Chem simulation are generally lower and less variable than in TES. The differences TES - GEOSChem vary between -10 to +25 ppbv. But again, as for the particular case presented previously, the difference between the GEOS-Chem simulations with and without the lightning source shows that the model generally predicts an ozone enhancement due to lightning at the TES locations where recent influence from lightning (large filled dots) is expected according to the analysis of forward trajectories emanating from NLDN and LRLDN observations. This suggests that the model captures the spatial pattern of ozone enhancement due to lightning. Cooper et al. (2007) based on IONS campaign and model simulations find a very similar ozone enhancement pattern due to lightning for summer 2006 (see their Figs. 2c and 3c). This also further confirms the signature of convection and lightning events in the TES data indicating that TES data can be used to investigate lightning emissions over the US in conjunction with the GEOS-Chem model.
However, the last figure in Fig. 6 shows clearly that differences between GEOS-Chem and TES are not only observed in the air masses recently influenced by lightning but also everywhere, in particular at high latitudes, where low influence from lighting is expected. The spatial pattern of the difference between GEOS-Chem and TES suggests that the underestimation of several sources and among them the stratospheric source could potentially contribute to the underestimation of the ozone concentrations in the upper troposphere, as suggested by the analysis of the vertical variation of the difference between GEOS-Chem and sondes (Sect. 2.5). In the following, we focus on the treatment of the lightning source in global models (here GEOS-Chem) using information from TES ozone, NLDN and LRLDN data. More particularly, we test whether improving the lightning distribution and increasing the $\mathrm{NO}_{\mathrm{x}}$ production by lightning in the model would reduce the discrepancy between TES and GEOS-Chem. 

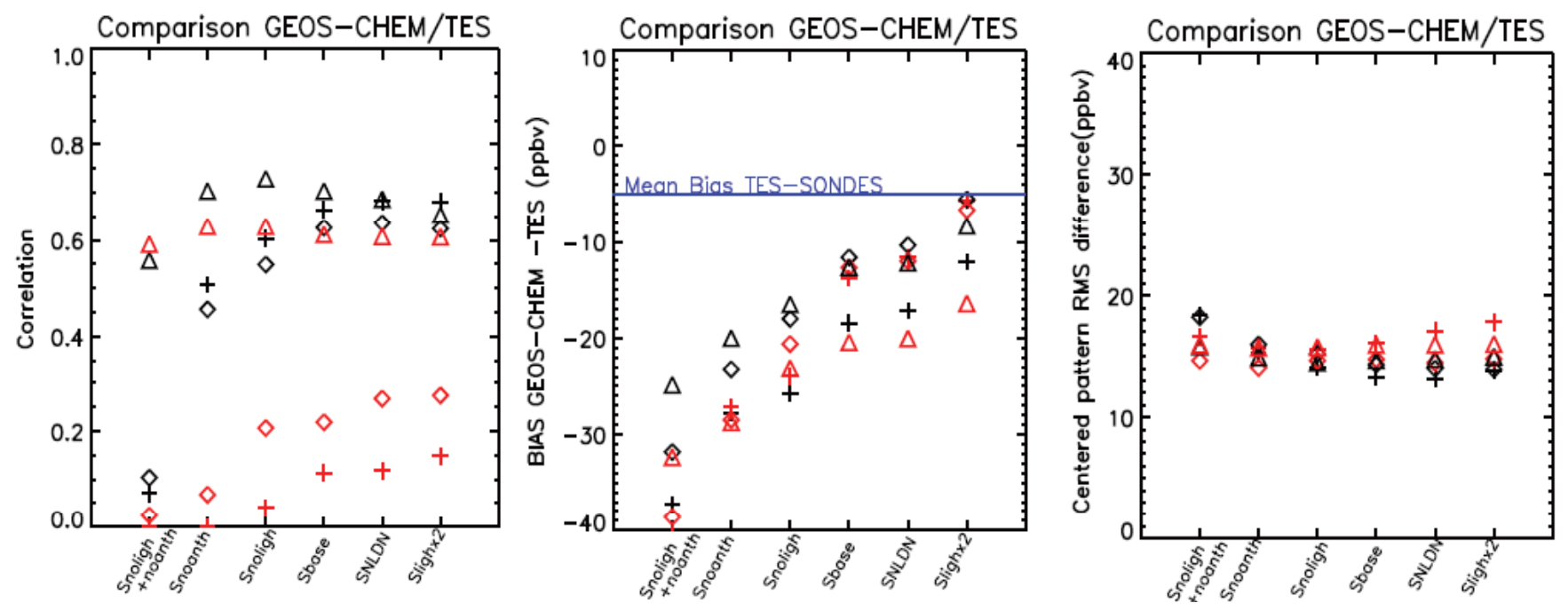

Fig. 7. Comparison between TES ozone and GEOS-Chem ozone at $300 \mathrm{hPa}$ in terms of correlation (left), mean bias (middle), centered pattern RMS difference (right) for 6 different regions and the Snoligh+noanth, Snoligh, Sbase, SNLDN, Slighx2 GEOS-Chem simulations (see text for definition of these simulations). The red symbols are for the 60-90 W longitude band, black symbols are for the 120-90 W longitude band. Triangles are for the 40-50 N latitude band, diamonds for the 30-40 N latitude band, plus for the $25-30 \mathrm{~N}$ latitude band. Distinction is made between these different regions because TES a priori varies. The different regions are presented in Fig. 1.

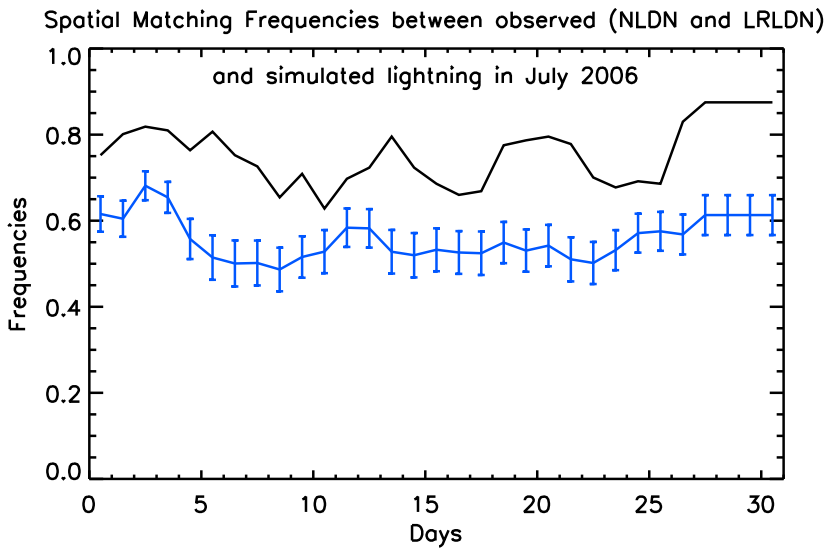

Fig. 8. Frequencies of spatial matching between the observed (NLDN and LRLDN) and simulated daily lightning distributions in July 2006 (black line). Expected frequencies \pm standard deviations due to randomness (blue line). NLDN and LRLDN were averaged over the grid box of the GEOS-Chem model.

\subsection{Sensitivity studies to the lightning distributions and $\mathrm{NO}_{\mathrm{x}}$ production per flash}

In this section, we perform two sensitivity studies, one to the lightning distribution and the other one to the value of the $\mathrm{NO}_{\mathrm{x}}$ production per flash in the GEOS-Chem model. We compare TES and GEOS-Chem in terms of correlation, biases and centered pattern RMS difference. We have split the data into 6 regions defined by 3 latitude bands and 2 longitude bands because the TES a priori is different in these
6 regions (see Fig. 1). This ensures that the variability in the TES data is from TES rather than from the TES a priori. We also consider only the data for which the DOF between $500 \mathrm{hPA}$-tropopause is equal or larger than 1 to ensure that TES has sensitivity.

\subsubsection{Sensitivity studies to the lightning distribution over the United States}

In $S_{\text {base }}$, the lightning activity in the model is scaled to OTD/LIS climatology on a regional and monthly basis to realistically distribute the $6 \mathrm{Tg} \mathrm{N} / \mathrm{yr}$ of NO produced by lightning over the globe and throughout the year. This means that the lightning is uniformly scaled over the United States, but the relative distribution of lightning intensities within the United States still relies on Price and Rind (1992) and the convection simulated by GEOS4. However, as demonstrated by Boccippio (2002), the parameterization of Price and Rind (1992) cannot fully represent the regional variability of lightning activity. In addition, several studies pointed out that GEOS4 meteorological dataset has some biases, in particular, cloud top height (Hudman et al., 2007). As a result, the correlation between daily lightning activity values in the $S_{\text {base }}$ simulation and observed by NLDN and LRLDN ranges only between 0.3 and 0.5 over the US (not shown). Therefore we test whether imposing the distribution of lightning intensities according to observations can explain part of the discrepancy between model and observations. In the simulation $S_{\mathrm{NLDN}}$, lightning flashes in GEOS-Chem are scaled on a daily basis to the NLDN and LRLDN observations for each particular grid box where lightning is simulated in the 
GEOS-Chem model (see Sect. 2.2). We observe that the correlation between TES and GEOS-Chem ozone changes only slightly in the $S_{\text {NLDN }}$ simulation compared to $S_{\text {base }}$ (Fig. 7). This suggests that even though the model does not reproduce the relative lightning intensities observed by NLDN, this cannot account for the difference between TES and GEOSChem. Furthermore, we see that the correlation between TES and GEOS-Chem is only slightly sensitive to the presence of $\mathrm{NO}_{\mathrm{x}}$ from lightning $\left(\mathrm{S}_{\text {noligh }}\right)$. This leads to look at the correlation between TES and the simulation without surfaces sources $\left(S_{\text {noanth }}\right)$ as well as the simulation $S_{\text {noligh }+ \text { noanth }}$ for which lightning and anthropogenic sources over North America have been turned off. We see that the correlation is only slightly sensitive to the absence of $\mathrm{NO}_{\mathrm{x}}$ from lightning $\left(S_{\text {noligh }}\right)$ or from surfaces sources $\left(S_{\text {noanth }}\right)$. But when these 2 sources are omitted $\left(S_{\text {noligh+noanth }}\right)$, ie. ozone precursors do not emanate from convective grid box, the model fails capturing the ozone variability exhibited by TES. As seen in Fig. 7, only one of these sources is necessary to reproduce most of the observed variability, as they both have the same spatial distribution, linked to the spatial distribution of the convective activity. Figure 8 presents the frequencies of spatial matching between observed and simulated daily lightning distributions for each day of July 2006. We follow Price and Rind (1992) to calculate the frequencies of spatial matching. The gridboxes having a non-null daily lightning activity are assigned the value 1 and the gridboxes having a null daily lightning activity are assigned a value of 0 . If both observations and calculations have a value of 1 or 0 , they match spatially. Otherwise, if the values are different, they are not spatially in agreement. The expected frequencies \pm standard deviations due to randomness are also calculated according to Price and Rind (1992). The total number of matching gridboxes varies approximately between $65 \%$ and $90 \%$. This number is more than one standard deviation larger than what would be expected under complete randomness. This suggests that the spatial pattern of the convective activity occurrence over the USA in July 2006 is correctly reproduced by the model on a daily basis. This is likely due to the fact that GEOS-Chem runs with assimilated meteorology.

To conclude, the model's ability to reproduce the location of the ozone enhancements seen by TES is due to the fact that this model reproduces the pattern of the occurrence of convective events and their associated lightning on a daily basis during the summer of 2006, even though it does not well represent the relative distribution of lightning flash intensities.

\subsubsection{Sensitivity studies to the $\mathrm{NO}_{\mathrm{x}}$ production per flash}

We investigate the sensitivity of our results to the lightning $\mathrm{NO}_{\mathrm{x}}$ production/Flash. We use a production of 520 molecules of NO/Flash very close to the one found by DeCaria et al. (2005) ( $460 \mathrm{~mol} / \mathrm{Flash}$ ) and the mean value found by Ott et al. (2010). This updated value was also used by Hudman et al. (2007) (500 mol/Flash), who found bet- ter agreement between the GEOS-Chem $\mathrm{NO}_{\mathrm{x}}$ field and measurements from the ICARTT campaign. In our case, the bias between GEOS-Chem and TES is reduced by about $40 \%$, it now ranges between -18 to $-6 \mathrm{ppbv}$, compared to between -22 ppbv to $-12 \mathrm{ppbv}$ previously (Fig. 7). This is still larger than the bias between sondes and TES at this level of $-5 \mathrm{ppbv}$ (see Fig. 3). This simulation is also compared to IONS ozonesondes. The difference between IONS and GEOS-Chem decreases by $10 \mathrm{ppbv}$ when the production per flash is doubled. However, the correlation between the TES and GEOS-Chem field does not improve. A closer look at scatter plots of TES vs. GEOS-Chem (not shown) indicates that the ozone in the model is scaled up everywhere. As a result, the model now slightly overestimates the low ozone values not influenced by recent lightning emissions. Indeed, with the increased $\mathrm{NO}_{\mathrm{x}}$ production/Flash, lightning occurring in midlatitudes in Europe and Asia increase the ozone background in the upper troposphere in the US.

It is important to note that we use the vertical distribution of $\mathrm{NO}_{\mathrm{x}}$ produced by lightning given by Pickering et al. (1998). More recently, Ott et al. (2010) used a 3-D cloud scale chemical transport model that includes a parameterized source of lightning $\mathrm{NO}_{\mathrm{x}}$ source based on observed flash rates to simulate six midlatitudes and subtropical thunderstorms. This study suggests that our model using Pickering et al. (1998) may place too much $\mathrm{NO}_{\mathrm{x}}$ near the surface and upper troposphere and too little in the middle troposphere at mid-latitudes. Ott et al. (2010) calculates the impact on the tropospheric ozone at the global scale using the GMI (Global Modeling Initiative) model and show that it leads to a decrease of the ozone in the upper troposphere up to $10 \mathrm{ppbv}$. This indicates that implementing the new profiles would lead to an additional small negative bias for ozone in the uppermost troposphere in the model. Thus, it would indicate that the lightning $\mathrm{NO}_{\mathrm{x}}$ production/Flash found in our work may be underestimated.

\section{Conclusions}

We find ozone enhanced layers downwind of lightning flashes in TES data over the United States in summer 2006 using lightning observations from NLDN and LRLDN as well as the HYSPLIT model. The global chemistry transport model GEOS-Chem with lightning activity calculated with the Price and Rind (1992) parameterization, scaled to OTD/LIS climatology, and with a production of $260 \mathrm{~mol}$ $\mathrm{NO} /$ Flash captures the ozone enhancements seen by TES. A sensitivity study performed with this model confirms the influence of the $\mathrm{NO}_{\mathrm{x}}$ lightning emissions on these enhancements. However, we find that the model generally underestimates these ozone enhancements and the differences between TES and GEOS-Chem are larger than the TES observational errors. 
We tested whether this discrepancy between TES and model could be due to a deficiency of the lightning parameterization. Two sensitivities studies, one to the distribution of the lightning source and the other one to the strength of the source, have been performed. We find that imposing the NLDN lightning distribution in the model on a daily basis does not change the location of the ozone enhancements from lightning in the model, and only slightly changes the magnitude of these enhancements as more lightning are observed in 2006 in NLDN than in OTD/LIS climatology. We show that the model's ability to reproduce the location of the enhancements is due to the fact that this model reproduces the pattern of the occurrence of the convective events on a daily basis during the summer of 2006, even though it does not well represent the relative distribution of lightning flash intensities.

We tested whether increasing the NO production per flash would reduce the discrepancy between TES and the GEOSChem model. For this test, we used the value of $520 \mathrm{NO}$ $\mathrm{mol} /$ Flash, for lightning occurring in midlatitudes, that better agrees with the values proposed by the recent studies of DeCaria et al. (2005) and Ott et al. (2010). At $300 \mathrm{hPa}$, the mean bias between TES and the original GEOS-Chem is between -22 and -12 ppbv depending the latitude band. With the increased NO/Flash production, the bias is now between -18 and -6 ppbv. This is still larger than the bias between sondes and TES at this level of -5 ppbv. However, this improvement should be considered with caution. Indeed, the ozone in the GEOS-Chem simulations is biased low in the upper troposphere by $15-30 \mathrm{ppbv}$ compared to the ozonesondes with the bias increasing with altitude and latitude, suggesting the stratospheric contribution to tropospheric ozone is underestimated in the model. In addition, although the bias between TES and GEOS-Chem decreases in the simulation with the increased NO/Flash, the correlation improves only very slightly. One explanation for this is that GEOS-Chem now overestimates the ozone background as compared to TES. Other factors that could be impacting the bias and correlations between TES and GEOS-Chem are deficiencies in the efficiency of the convective transport of pollution (Folkins et al., 2006), or in the emissions of the ozone precursors at the surface in the model. For the latter, it is important to note that $\mathrm{NO}_{\mathrm{x}}$ surface sources from NEI99 and soil emissions had not been updated from the more recent estimates (Hudman et al., 2007; Jaegle et al., 2005) in the present study. However, this update would likely lead to less ozone production. It is also important to note that if we used the vertical distribution of lightning $\mathrm{NO}_{\mathrm{x}}$ of Ott et al. (2010) instead of Pickering et al. (1998), the bias between TES and GEOS-Chem ozone would increase in the upper troposphere.

Since TES data provide direct measurements of ozone enhanced layers from lightning, they constitute a valuable dataset for characterizing ozone production from lightning $\mathrm{NO}_{\mathrm{x}}$ emissions. TES can provide a unique capability to cam- paigns focused on understanding the influence of convection and lightning on the chemistry of the upper troposphere over the United States, such as the Deep Convective Clouds and Chemistry experiment (DC3) planned for the summer 2012. In this framework, TES ozone profiles could be used to constrain model calculations in conjunction with additional data collected during the campaign, particularly $\mathrm{NO}_{\mathrm{x}}$ and $\mathrm{OH}$ concentrations in the upper troposphere which affect ozone production and lifetime. This campaign will also involve different chemistry transport models, including global and regional models, which could help better understand limitations of the models, as indicated by our findings, in terms of treatment of the stratosphere, convection, and model resolution and their impacts on the interpretation of the data. In particular, given that the IONS sondes reveal stratospheric influences are important (Thompson et al., 2007a, b, 2008; Yorks et al., 2009) when upper tropospheric ozone is elevated over the summertime US, the treatment of the stratospheric ozone flux in global models merits further investigation.

Acknowledgements. This work was performed at the Jet Propulsion Laboratory, California Institute of Technology, under a contract with the National Aeronautics and Space Administration. We thank Rynda Hudman at Harvard University for helpful discussions. We used the v0.1 gridded OTD/LIS satellite lightning data produced by the NASA LIS/OTD Science Team (Principal Investigator, Hugh J. Christian, NASA/Marshall Space Flight Center) and available from the Global Hydrology Resource Center (GHRC) (http://ghrc.msfc.nasa.gov), We also used the NLDN and LRLDN data collected by Vaisala, Inc. and archived and distributed by GHRC. We are grateful to the NOAA Air Resources Laboratory (ARL) for the provision of the HYSPLIT transport and dispersion model (http://www.arl.noaa.gov/ready/hysplit4.html).

Edited by: T. Wagner

\section{References}

Beer, R., Glavich, T. A., and Rider, D. M.: Tropospheric emission spectrometer for the Earth Observing System's Aura satellite, Appl. Optics, 40, 2356-2367, 2001.

Beer, R.: TES on the Aura mission: Scientific objectives, measurements, and analysis overview, IEEE T. Geosci. Remote, 44, 1102-1105, 2006.

Boccippio, D. J., Cummins, K. L., Christian, H. J., et al.: Combined satellite- and surface-based estimation of the intracloud-cloudto-ground lightning ratio over the continental United States, Mon. Weather Rev., 129, 108-122, 2001.

Boccippio, D. J.: Lightning Scaling Relations Revisited, Atmos. Environ., 59, 1086-1104, 2002.

Bowman, K. W., Rodgers, C. D., Kulawik, S. S., Worden, J., Sarkissian, E., Osterman, G., Steck, T., Lou, M., Eldering, A., Shephard, M., Worden, H., Lampel, M., Clough, S., Brown, P., Rinsland, C., Gunson, M., and Beer, R.: Tropospheric Emission Spectrometer: Retrieval Method and Error Analysis, IEEE T. Geosci. Remote, 44, 1297-1307, 2006. 
Brunner, D., Staehelin, J., and Jeker, D.: Large-Scale Nitrogen Oxide Plumes in the Tropopause Region and Implications for Ozone, Science, 182, 1305-1309, 1998.

Brunner, D., Staehelin, J., Jeker, D., Wernli, H., and Schumman, U.: Nitrogen oxides and ozone in the tropopause region of the Northern Hemisphere : Measurements from commercial aircraft in 1995/1996 and 1997, J. Geophys. Res., 106, 27673-27699, 2001.

Christian, H. J., Blakeslee, R. J., Boccippio, D. J., Boeck, W. L., Buechler, D. E., Driscoll, K. T., Goodman, S. J., Hall, J. M., Koshak, W. J., Mach, D. M., and Stewart, M. F.: Global frequency and distribution of lightning as observed from space by the Optical Transient Detector, J. Geophys. Res., 108, 4005, doi:10.1029/2002JD002347, 2003.

Cooper, O. R., Stohl, A., Trainer, M., Thompson, A. M., Witte, J. C., Oltmans, S. J., Morris, G., Pickering, K. E., Crawford, J. H., Chen, G., Cohen, R. C., Bertram, T. H., Wooldridge, P., Perring, A., Brune, W. H., Merrill, J., Moody, J. L., Tarasick, D., Nédélec, P., Forbes, G., Newchurch, M. J., Schmidlin, F. J., Johnson, B. J., Turquety, S., Baughcum, S. L., Ren, X., Fehsenfeld, F. C., Meagher, J. F., Spichtinger, N., Brown, C. C., McKeen, S. A., McDermid, I. S., and Leblanc, T.: Large upper tropospheric ozone enhancements above mid-latitude North America during summer: In situ evidence from the IONS and MOZAIC ozone measurement network, J. Geophys. Res., 111, D24S05, doi:10.1029/2006JD007306, 2006.

Cooper, O. R., Trainer, M., Thompson, A. M., Oltmans, S. J., Tarasick, D. W., Witte, J. C., Stohl, A., Eckhardt, S., Lelieveld, J., Newchurch, M. J., Johnson, B. J., Portmann, R. W., Kalnajs, L., Dubey, M. K., Leblanc, T., McDermid, I. S., Forbes, G., Wolfe, D., Carey-Smith, T., Morris, G. A., Lefer, B., Rappenglück, B., Joseph, E., Schmidlin, F., Ravishankara, A., Meagher, J., Fehsenfeld, F. C., Keating, T. J., Van Curen, R. A., and Minschwaner, K.: Evidence for a recurring eastern North American upper tropospheric ozone maximum during summer, J. Geophys. Res., 112, D23306, doi:10.1029/2007JD008910, 2007.

Crawford, J., Davis, D., Olson, J., Chen, G., Liu, S., Fuelberg, H., Hannan, J., Kondo, Y., Anderson, B., Gregory, G., Sachse, G., Talbot, R., Viggiano, A., Heikes, B., Snow, J., Singh, H., and Blake, D.: Evolution and chemical consequences of lightningproduced $\mathrm{NO}_{\mathrm{x}}$ observed in the North Atlantic upper troposphere, J. Geophys. Res., 105, 19795-19809, 2000.

DeCaria, A. J., Pickering, K. E., Stenchikov, G. L., Scala, J. R., Stith, J. L., Dye, J. E., Ridley, B. A., and Laroche, P.: A cloudscale model study of lightning-generated $\mathrm{NO}_{\mathrm{x}}$ in an individual thunderstorm during STERAO-A, J. Geophys. Res., 105, 1160111616, 2000.

DeCaria, A. J., Pickering, K. E., Stenchikov, G. L., and Ott, L. E.: Lightning-generated $\mathrm{NO}_{\mathrm{x}}$ and its impact on tropospheric ozone production: A three-dimensional modeling study of a Stratosphere-Troposphere Experiment: Radiation, Aerosols and Ozone (STERAO-A) thunderstorm, J. Geophys. Res., 110, D14303, doi:10.1029/2004JD005556, 2005.

Draxler, R. R. and Rolph, G. D.: HYSPLIT (Hybrid Single-Particle Lagrangian Integrated Trajectory) model. Web address: http: //www.arl.noaa.gov/ready/hysplit4.html, NOAA Air Resources Laboratory, Silver Spring, MD, 2003.

Folkins, I., Bernath, P., Boone, C., Donner, L. J., Eldering, A., Lesins, G., Martin, R. V., Sinnhuber, B.-M., and Walker,
K.: Testing convective parameterizations with tropical measurements of $\mathrm{HNO}_{3}, \mathrm{CO}, \mathrm{H}_{2} \mathrm{O}$, and $\mathrm{O}_{3}$ : Implications for the water vapor budget, J. Geophys. Res., 111, D23304, doi:10.1029/2006JD007325, 2006.

Grogan, M. J.: Report on the 2002-2003 US NLDN system-wide upgrade, Vaisala Thunderstorm, Tuscon, Ariz., 2004.

Horowitz, L., Walters, S., Mauzerall, D., Emmons, L., Rasch, P., Granier, C., Tie, X., Lamarque, J.-F., Schultz, M., Tyndall, G., Orlando, J., and Brasseur, G.: A global simulation of tropospheric ozone and related tracers: Description and evaluation of MOZART, version 2, J. Geophys. Res., 108, 4784, doi:10.1029/2002JD002853, 2003.

Hudman, R. C., Jacob, D. J., Turquety, S., Leibensperger, E. M., Murray, L. T., Wu, S., Gilliland, A. B., Avery, M., Bertram, T. H., Brune, W., Cohen, R. C., Dibb, J. E., Flocke, F. M., Fried, A., Holloway, J., Neuman, J. A., Orville, R., Perring, A., Ren, X., Sachse, G. W., Singh, H. B., Swanson, A., and Wooldridge, P. J.: Surface and lightning sources of nitrogen oxides over the United States: Magnitudes, chemical evolution, and outflow, J. Geophys. Res., 112, D12S05, doi:10.1029/2006JD007912, 2007.

Huntrieser, H., Schumann, U., Schlager, H., Höller, H., Giez, A., Betz, H.-D., Brunner, D., Forster, C., Pinto Jr., O., and Calheiros, R.: Lightning activity in Brazilian thunderstorms during TROCCINOX: implications for $\mathrm{NO}_{\mathrm{x}}$ production, Atmos. Chem. Phys., 8, 921-953, 2008,

http://www.atmos-chem-phys.net/8/921/2008/.

Jaeglé, L., Jacob, D. J., Wang, Y., Weinheimer, A. J., Ridley, B. A., Campos, T. L., Sasche, G. W., and Hagen, D. E.: Sources and chemistry of $\mathrm{NO}_{\mathrm{x}}$ in the upper troposphere over the United Stated, Geosphys. Res. Lett., 25, 1705-1708, 1998.

Jaeglé, L., Steinberger, L., Martin, R. V., and Chance, K.: Global partitioning of $\mathrm{NO}_{\mathrm{x}}$ sources using satellite observations: Relative roles of fossil fuel combustion, biomass burning and soil emissions, Faraday Discuss., 130, 407-423, 2005.

Jeker, D. P., Pfister, L., Thompson, A. M., Brunner, D., Boccipio, D. J., Pickering, K. E., Wernli, H., Kondoa, Y., and Staehelin, J.: Measurements of nitrogen oxides at the tropopause: Attribution to convection and correlation with lightning, J. Geophys. Res., 105, 3679-3700, 2000.

Jourdain, L., Worden, H. M., Worden, J. R., Bowman, K., Li, Q., Eldering, A., Kulawik, S. S., Osterman, G., Boersma, K. F., Fisher, B., Rinsland, C. P., Beer, R., and Gunson, M.: Tropospheric vertical distribution of tropical Atlantic ozone observed by TES during the northern African biomass burning season, Geophys. Res. Lett., 34, L04810, doi:10.1029/2006GL028284, 2007.

Li, D. and Shine, K. P.: A 4-Dimensionnal Ozone Climatology for UGAMP Models, UGAMP Internal Report N 35, 1995.

Li, Q., Jacob, D. J., Park, R., Wang, Y., Heald, C. L., Hudman, R., Yantosca, R. M., Martin, R. V., and Evans, M.: North American pollution outflow and the trapping of convectively lifted pollution by upper-level anticyclone, J. Geophys. Res., 110, D10301, doi:10.1029/2004JD005039, 2005.

Liu, S. C., Yu, H., Wang, Y., Davis, D. D., Kondo, Y., Anderson, B. E., Sachse, G. W., Gregory, G. L., Ridley, B., Fuelburg, H. E., Thompson, A. M., and Singh, H. B.: Sources of reactive nitrogen in the upper troposphere during SONEX, Geophys. Res. Lett., 26, 2441-2444, 1999.

Martin, R. V., Sioris, C. E., Chance, K., Ryerson, T. B., Bertram, T. H., Wooldridge, P. J., Cohen, R. C., Neuman, J. A., Swanson, 
A., and Flocke, F. M.: Evaluation of space-based constraints on global nitrogen oxide emissions with regional aircraft measurements over and downwind of eastern North America, J. Geophys. Res., 111, D15308, doi:10.1029/2005JD006680, 2006.

McLinden, C. A., Olsen, S. C., Hannegan, B., Wild, O., Prather, M. J., and Sundet, J.: Stratospheric ozone in 3-D models: A simple chemistry and the cross-tropopause flux, J. Geophys. Res., 105, 14653-14666, 2000.

Nassar, R., Logan, J. A., Worden, H. M., Megretskaia, I. A., Bowman, K. W., Osterman, G. B., Thompson, A. M., Tarasick, D., Austin, S., Claude, H., Dubey, M., Hocking, W., Johnson, B., Joseph, E., Merrill, J. T., Morris, G., Newchurch, M. J., Oltmans, S., Posny, F., Schmidlin, F., Vömel, H., Whiteman, D., and Witte, J.: Validation of Tropospheric Emission Spectrometer (TES) Nadir Ozone Profiles Using Ozonesonde Measurements, J. Geophys. Res., 113, D15S17, doi:10.1029/2007JD008819, 2008.

Osterman, G. B., Kulawik, S. S., Worden, H. M., Richards, N. A. D., Fisher, B. M., Eldering, A., Shephard, M. W., Froidevaux, L., Labow, G., Luo, M., Herman, R. L., Bowman, K. W., and Thompson, A. M.: Validation of Tropospheric Emission Spectrometer (TES) Measurements of the Total, Stratospheric and Tropospheric Column Abundance of Ozone, J. Geophys. Res., 113, D15S16, doi:10.1029/2007JD008801, 2008.

Ott, L. E., Pickering, K. E., Stenchikov, G. L., DeCaria, A. J., Lin, R.-F., Wang, D., Lang, S., and Tao, W.-K.: Production of lightning $\mathrm{NO}_{\mathrm{x}}$ and its vertical distribution calculated from 3-D cloudscale transport model simulations, J. Geophys. Res., in press, 2010.

Park, M., Randel, W. J., Kinnison, D. E., Garcia, R. R., and Choi, W.: Seasonal variation of methane, water vapor, and nitrogen oxides near the tropopause: Satellite observations and model simulations, J. Geophys. Res., 109, D03302, doi:10.1029/2003JD003706, 2004.

Parrington, M., Jones, D. B. A., Bowman, K. W., Horowitz, L. W., Thompson, A. M., Tarasick, D., and Witte, J. C.: Constraining the Summertime Tropospheric Ozone Distribution over North America through Assimilation of Observations from the Tropospheric Emission Spectrometer, J. Geophys. Res., 113, D18307, doi:10.1029/2007JD009341, 2008.

Pickering, K. E., Wang, Y., Tao, W.-K., Price, C., and Müller, J.F.: Vertical distributions of lightning $\mathrm{NO}_{\mathrm{x}}$ for use in regional and global chemical transport models, J. Geophys. Res., 103, 3120331216, doi:10.1029/98JD02651, 1998.

Price, C. and Rind, D.: A simple lightning parameterization for calculating global lightning distributions, J. Geophys. Res., 97, 9919-9933, 1992.

Richards, N. A. D., Osterman, G. B., Browell, E. V., Hair, J. W., Avery, M., and Li, Q.: Validation of Tropospheric Emission Spectrometer ozone profiles with aircraft observations during the Intercontinental Chemical Transport Experiment-B, J. Geophys. Res., 113, D16S29, doi:10.1029/2007JD008815, 2008.

Ridley, B. A., Walega, J. G., Dye, J. E., and Grahek, F. E.: Distributions of $\mathrm{NO}, \mathrm{NO}_{\mathrm{x}}, \mathrm{NO}_{\mathrm{y}}$, and $\mathrm{O}_{3}$ to $12 \mathrm{~km}$ altitude during the summer monsoon season over New Mexico, J. Geophys. Res., 99(D12), 25519-25534, doi:10.1029/94JD02210, 1994.

Rodgers, C. D.: Inverse Methods for Atmospheric Sounding: Theory and Practise, Singapore: World Scientific, Series on Atmospheric, Oceanic and planetary physics, 2, 1-11, 2000.
Sauvage, B., Martin, R. V., van Donkelaar, A., Liu, X., Chance, K., Jaeglé, L., Palmer, P. I., Wu, S., and Fu, T.-M.: Remote sensed and in situ constraints on processes affecting tropical tropospheric ozone, Atmos. Chem. Phys., 7, 815-838, 2007, http://www.atmos-chem-phys.net/7/815/2007/.

Schumann, U. and Huntrieser, H.: The global lightning-induced nitrogen oxides source, Atmos. Chem. Phys., 7, 3823-3907, 2007, http://www.atmos-chem-phys.net/7/3823/2007/.

Stith, J., Dye, J., Ridley, B., Laroche, P., Defer, E., Baumann, K., Hübler, G., Zerr, R., and Venticinque, M.: NO signatures from lightning flashes, J. Geophys. Res., 104, 16081-16089, 1999.

Thompson, A. M., Pickering, K. E., Dickerson, R. R., Ellis, W. G., Jacob, D. J., Scala, J. R., Tao, W. K., McNamara, D. P., and Simpson, J.: Convective Transport over the central United States and its role in regional CO and ozone budgets, J. Geophys. Res., 99, 18703-18711, 1994.

Thompson, A. M., Sparling, L. C., Kondo, Y., Anderson, B. E., Gregory, G. L., and Sachse, G. W.: Perspectives on NO, NOy and fine aerosol sources and variability during SONEX, Geophys. Res. Lett., 26, 3073-3076, 1999.

Thompson, A. M., Stone, J. B., Witte, J. C., et al.: Intercontinental Chemical Transport Experiment Ozonesonde Network Study (IONS) 2004: 1. Summertime upper troposphere/lower stratosphere ozone over northeastern North America, J. Geophys. Res., 112, D12S12, doi:10.1029/2006JD007441, 2007a.

Thompson, A. M., Stone, J. B., Witte, J. C., et al.: Intercontinental Chemical Transport Experiment Ozonesonde Network Study (IONS) 2004: 2. Tropospheric ozone budgets and variability over northeastern North America, J. Geophys. Res., 112, D12S13, doi:10.1029/2006JD007670, 2007b.

Thompson, A. M., Yorks, J. E., Miller, S. K., Witte, J. C., Dougherty, K. M., Morris, G. A., Baumgardner, D., Ladino, L., and Rappenglück, B.: Tropospheric ozone sources and wave activity over Mexico City and Houston during MILAGRO/Intercontinental Transport Experiment (INTEX-B) Ozonesonde Network Study, 2006 (IONS-06), Atmos. Chem. Phys., 8, 5113-5125, 2008,

http://www.atmos-chem-phys.net/8/5113/2008/.

Wang, Y., Logan, J. A., and Jacob, D. J.: Global simulation of tropospheric $\mathrm{O} 3-\mathrm{NO}_{\mathrm{x}}$-hydrocarbon chemistry 2 . Model evaluation and global ozone budget, J. Geophys. Res. 103, 10727-10755, 1998.

Worden, J., Kulawik, S. S., Shephard, M. W., Clough, S. A., Worden, H., Bowman, K., and Goldman, A.: Predicted errors of tropospheric emission spectrometer nadir retrievals from spectral window selection, J. Geophys. Res., 109, D09308, doi:10.1029/2004JD004522, 2004.

Worden, H. M., Logan, J. A., Worden, J. R., Beer, R., Bowman, K., Clough, S. A., Eldering, A., Fisher, B. M., Gunson, M. R., Herman, R. L., Kulawik, S. S., Lampel, M. C., Luo, M., Megretskaia, I. A., Osterman, G. B., and Shephard, M. W.: Comparisons of Tropospheric Emission Spectrometer (TES) ozone profiles to ozonesondes: Methods and initial results, J. Geophys. Res., 112, D03309, doi:10.1029/2006JD007258, 2007.

Yorks, J. E., Thompson, A. M., Joseph, E., and Miller, S. K.: The variability of free tropospheric ozone budgets over Beltsville, Maryland (39 N, 77 W) in the summers 2004-2007, Atmos. Environ., 43, 1827-1838, 2009. 